\title{
E-LEARNING W NAUCZANIU MEDYCZNEGO JĘZYKA ANGIELSKIEGO
}

\section{ANNA BĄCZKOWSKA}

\section{E-LEARNING IN TEACHING MEDICAL ENGLISH}

ABSTRACT The aim of the present article is to describe the methods and forms of e-learning implemented to classes of medical English to Polish students in the summer semester in 2020 at Nicolaus Copernicus University (NCU) in Torun. The theoretical framework of the proposed e-learning was based on the assumptions voiced by constructivism. The article also discusses the results of two anonymous surveys concerning classes of medical English, which were administered among students of Collegium Medicum NCU. The first survey was administered after one week of e-learning (in March) and the second one after the last class of e-learning (in June). Over one hundred respondents took part in each survey. A number of apps were used in the distance education described in the article, inter alia: MS Teams, MS Forms, Fiszkoteka, Kahoot, LearnClick, OBS Studio, YouTube, etc. The results of the surveys demonstrate that a vast number of students who took part in the online course of medical English were satisfied with this form oflearning, which they found effective, motivating and attractive.

KEY WORDS e-learning, constructivism, educational platforms, survey CONTACT Instytut Anglistyki i Amerykanistyki; anna.baczkowska@ug.edu.pl 


\section{$1 /$ NAUCZANIE ZDALNE: PODSTAWY TEORETYCZNE}

Podejście teoretyczne do e-learningu (pol. edukacja elektroniczna) reprezentowane przez opisane poniżej badanie ilustruje koncepcje promowane przez nurt konstruktywistyczny w pedagogice. Konstruktywizm jest ogólnie znaną teorią w pedagogice wywodzącą się z założeń Jeana Piageta, Lwa Wygotskiego i Jeremiego Brunera (Fosnot 2005; Bączkowska 2010; Filipiak 2011). Zakłada on, podobnie jak kogniwtywizm Noama Chomskiego, że człowiek jest istotą myślącą oraz że potrafi aktywnie konstruować wiedzę w swoim umyśle w wyniku interakcji podmiotu $\mathrm{z}$ jego otoczeniem (co podkreśla Jean Piaget) i środowiskiem, czyli dorosłymi w jego otoczeniu (co jest warunkiem koniecznym rozwoju podmiotu u Lew Wygotskiego). Wiedza jest zatem konstruktem, powstającym na bazie informacji już zdobytej we wcześniejszym doświadczeniu poprzez proces asymilacji generalizacji i akomodacji (Piaget i Inhelder 1967 [1948]); zob. Bączkowska 2010). Podmiot jest inicjatorem zdobywania wiedzy i jej konstruowania na własne potrzeby, co przesuwa punkt ciężkości procesu uczenia się z podmiotu zewnętrznego (np. nauczyciela czy osoby dorosłej w otoczeniu podmiotu, używając nomenklatury Wygotskiego) na sam podmiot, który obarczony jest największą odpowiedzialnością za efekty własnego uczenia się. Podmiot konstruuje wiedzę (wg Piaget), czyli uczy się - podejmując działania o charakterze proaktywnym - wchodząc w ukierunkowane uczestnictwo w „strefie najbliższego rozwoju” (wg Wygotsky). W tym procesie wspiera się na „rusztowaniu” (wg Brunera), które jest efektem wspólnego wysiłku „dziecka” i „dorosłego” w dążeniu do zdobywania nowej wiedzy i rozwiązywania problemów poprzez działanie (współpracę) i dopasowywanie zadań do możliwości ucznia.

Konstruktywistyczne zasady nauczania dzieci z powodzeniem można przełożyć na e-learning osób dorosłych, co uczyniłam w moim nauczaniu angielskiego języka specjalistycznego (medycznego) w Collegium Medicum Uniwersytetu Mikołaja Kopernika (dalej: CM UMK) w kształceniu zdalnym. Implementacja tych zasad polegała w szczególności na 1. tworzeniu maksymalnie sprzyjających warunków do nauki i do wykorzystania przez studentów swojego potencjału; 2. respektowaniu prawa studenta do rozwoju w indywidualnym tempie; 3. odwoływaniu się do wewnętrznej motywacji studentów; 4. uwzględnianiu podmiotowego stylu interakcji; 5. utrzymywaniu poziomu gotowości studenta do dalszej nauki poprzez wspieranie go w uzyskaniu maksymalnie wysokiego poziomu efektywności nauki. W myśl tych zasad nauczyciel jest przede wszystkim odpowiednikiem „dorosłego” z otoczenia podmiotu, czyli ucznia/studenta. Pełni on rolę osoby wspierającej proces uczenia się poprzez przyjmowanie funkcji tutora, doradcy i przewodnika, organizatora warunków sprzyjających uczeniu się i umożliwiających osiągnięcie przez ucznia samodzielności oraz ukończenie zadania na miarę jego możliwości.

Opisane w niniejszym artykule badanie odwołuje się do metod i form nauczania, które wpisują się w model e-edukacji znanej jako WBL (Web Based Learning). Istotą WBL jest to, że $\mathrm{w}$ nauczaniu wykorzystywane są materiały edukacyjne rozpowszechniane $\mathrm{w}$ internecie, a także, że może być ono realizowane w sposób asynchroniczny i synchroniczny. Narzędziami zastosowanymi w nauczaniu zdalnym były aplikacje i platformy wyposażone w systemy do zarządzania e-kursami (tzw. LMS, czyli Language Management System), które pomagały organizować treść zajęć i ich dystrybucję, monitorować postępy studentów i oceniać zajęcia; integrowały różne współpracujące ze sobą aplikacje, wspierały edytowanie treści i ich importowanie, magazynowały treści dydaktyczne oraz umożliwiały komunikację między wykładowcą i studentem. 
Zaproponowane przeze mnie rozwiązania realizowały założenie wstępne o konieczności maksymalnego zaangażowania studentów w proces uczenia, w którym prowadząca kurs miała jedynie służyć jako wsparcie, tworząc pomost między wiedzą aktualną studenta, a wiedzą docelową (budując swoiste „rusztowanie”). Przyświecał mi cel, aby studenci niejako uczyli się sami (jako proaktywni „konstruktorzy” własnej wiedzy), moja rola miała polegać na trafnym wyborze materiałów edukacyjnych pod względem skuteczności uczenia się i ich atrakcyjności dla studentów, aby zachęcić ich do włączenia się w proces poznawczy, przebywając w środowisku sprzyjającym uczeniu się. Zakładałam, że studenci pozbawieni bezpośredniego kontaktu z nauczycielem będą mieli większy problem z utrzymaniem motywacji do nauki niż miałoby to miejsce w nauczaniu stacjonarnym, ponieważ nauka zdalna wymaga dużej samodyscypliny, samokontroli i przejęcia odpowiedzialności za rezultaty nauki przez samego studenta.

Dążyłam zatem do eksponowania studentów na zmienne bodźce i krótki czas ekspozycji na nie, co było operacjolizowane poprzez zapewnianie różnorodności ćwiczeń i wprowadzanie elementu ograniczonego czasu wykonania zadania (np. na platformach Kahoot czy LearnClick), co z kolei miało wspierać utrzymanie uwagi i motywacji studenta do nauki. $Z$ tego też względu wprowadziłam nie tylko zróżnicowane typy ćwiczeń, ale też kilka platform edukacyjnych, z których każda sprawdzała wiedzę studentów w odmienny sposób, niekiedy zaskakując ich, pobudzając do wysiłku. Aktywacja studentów pozwoliła prowadzić kształcenie zorientowane na podmiot, w którym najwięcej pracy musiał wykonać sam student (choć pod kierunkiem nauczyciela), przejmując tym samym odpowiedzialność za swój proces uczenia się.

\section{2 / NAUCZANIE ZDALNE W PRAKTYCE}

Zajęcia, które prowadziłam w trakcie pandemii, od początku odbywały się na wybranej przeze mnie platformie MS Teams. Zajęcia odbywały się w ok. 70\%-80\% w formie asynchronicznej i ok. 20\%-30\% w formie synchronicznej (w zależności od dnia tygodnia, w których zaplanowane były zajęcia). Władze Uczelni musiały uporać się z sytuacją, którą można określić mianem kryzysu (Bączkowska 2020), nikt bowiem nie wiedział dokładnie jak sobie poradzić z sytuacją e-learningu, która zaskoczyła wszystkich interesariuszy; nauczanie zdalne bowiem nigdy dotąd nie było popularną formą kształcenia w Polsce. W konsekwencji oficjalne i wiążące wytyczne i zarządzenia zapadały późno, a ciężar decyzji dotyczących poradzenia sobie z sytuacją (pod względem merytorycznym i technicznym) w zasadzie spoczął na wykładowcach oraz studentach. Efektywność kształcenia zależała z kolei od stopnia ich współpracy.

\section{1 / Struktura strony}

Zajęcia asynchroniczne, które zaproponowałam moim studentom, polegały na utworzeniu przeze mnie Zespołów dla każdej grupy w aplikacji MS Teams i umieszczaniu materiałów w formie konspektów na karcie ,Ogólne’, w foldrze ,Materiały z zajęć'. Studenci mogli ściągać pliki z konspektami na swoje komputery, klikać umieszczone w nich linki przekierowujące ich do innych platform edukacyjnych (fiszek, testów, krzyżówek, filmów na YouTube itp.). Konspekty liczyły zwykle 2-4 strony A4. Zadania, które zlecane były studentom były, przez nich wgrywane do systemu MS Teams do poszczególnych Zespołów, a konkretnie do folderów, które każdy student sam zakładał na kanale ,ćwiczenia studentów'. Oprócz tego kanału utworzony 
był oddzielny kanał z linkami do ćwiczeń na platformie Kahoot (,Kahooty') oraz z zadaniami dla studentów utworzonymi w formie tekstów z lukami (kanał ,gap-filling generator'). Struktura Zespołu pozwalała zatem na interakcję z każdym studentem, który nie tylko czytał materiały przesłane przeze mnie do własnego opracowania, ale też wgrywał swoje prace do systemu. Uzyskane z testów wyniki z kolei zapisywane były automatycznie na kanale ,Ogólny' na karcie ,Oceny'. Podsumowując, każdy Zespół zawierał kilka takich samych kanałów: ,ćwiczenia studentów', ,gap-filling generator' oraz ,Kahoot'. Na kanale ogólnym natomiast korzystałam głównie z kart: ,Materiały z zajęć', ,Zadania', ,Oceny' oraz ,Pin-up Board' (tablica korkowa). Ta ostatnia zakładka została przeze mnie dodana do systemu i pełniła rolę swoistej tablicy ogłoszeń i terminarza, zapisywałam na niej zadania domowe oraz terminy testów, zadań, projektów itp.

\section{2 / Użyte aplikacje i platformy}

W celu urozmaicenia formy zajęć oraz zwiększenia ich skuteczności, głównie poprzez proponowanie różnorodnej formy ćwiczeń mających na celu wielokrotne utrwalanie materiału, zwiększanie jego atrakcyjności $\mathrm{w}$ trakcie prezentacji nowych treści oraz przede wszystkim podtrzymywanie, a nawet zwiększanie, motywacji studentów do uczenia się specjalistycznego języka angielskiego, oprócz aplikacji MS Teams korzystałam również z szeregu innych aplikacji, systemów i platform edukacyjnych omówionych poniżej.

MS Forms. Aplikacja ta używana była w celu sprawdzenia wiedzy z zakresu terminologii wprowadzanej w ramach danych zajęć oraz - przede wszystkim - stopnia opanowania gramatyki na wymaganym poziomie B2+ ESOKJ'. W sumie w aplikacji Forms utworzyłam 11 testów na kolokwia zaliczeniowe, 9 testów egzaminacyjnych oraz 7 testów powtórkowych z gramatyki (łącznie ponad 100 pytań testowych z gramatyki), a także 5 testów ze specjalistyczną terminologią medyczną dla studentów medycyny oraz terminologią z zakresu optometrii i okulistyki dla studentów studiów magisterskich na kierunku „optometria”.

Testy udostępniałam w dwóch wersjach: $w$ formie anonimowej oraz zaliczeniowej. Wersja anonimowa (udostępniana poprzez link do strony lub kod QR - patrz poniżej) pozwalała studentom wykonywać dany test wielokrotnie (tyle razy, ile student uznał za konieczne). Wyniki testu zaliczeniowego rejestrowane były automatycznie w Zespołach na karcie „Oceny”.

YouTube i inne portale z filmami wideo. Filmy wideo wykorzystywne były dwojako. Po pierwsze, w celu wprowadzenia nowego materiału, czemu służyły na przykład filmy dostępne na YT na temat różnych problemów medycznych i pracy lekarzy w W. Brytanii. Po drugie, filmy wideo wykorzystywane były w celu powtórzenia gramatyki, które nagrywane były przeze mnie i udostępnione na moim kanale YT. Filmy powtórkowe z gramatyki (na poziomie B2/C1) prowadzone były w formie miniwykładów i dotyczyły $\mathrm{m}$.in. czasowników modalnych $\mathrm{w}$ czasie przeszłym, powtórki z czasów gramatycznych, trybu lączącego (subjunctive), strony biernej, okresów warunkowych (w tym mieszanych). Wszelkie wątpliwości zatem dotyczące gramatyki były wpierw wyjaśniane na filmie, po czym student wykonywał test (anonimowy, a następnie rejestrowany i punktowany) sprawdzający zrozumienie treści. Filmy dotyczące gramatyki (udostępniane w trybie „niepublicznym”) cieszyly się bardzo dużym powodzeniem (w sumie zarejestrowano ok. 2500 wyświetleń). 
Oprócz YT wykorzystywałam również filmy dostępne m.in. na stronie National Health System w W. Brytanii (adres: https://www.nhs.uk/conditions) oraz na stronie autorskiej okulisty Tima Roota (adres: https://timroot.com). Filmy T. Roota nie posiadają transkrypcji, pisałam je w związku z tym sama, później wykorzystując je również do tworzenia ćwiczeń typu gap-filling generator oraz do tworzenia fiszek.

Kahoot. Platformy Kahoot używałam w celu sprawdzenia stopnia przyswojonej wiedzy w sposób przypominający rywalizajcę poprzez zabawę. Kahoot to platforma atrakcyjna graficznie, która bardzo angażuje uczących się i skupia uwagę na prezentowanych treściach.

Warto wspomnieć, że Kahoot pozwala tworzyć nie tylko testy, ale też mini wykłady. Tworzenie mini wykładów polegało na „wbudowaniu” wybranych filmów wideo dostępnych na YT w slajdy. Przykładowy slajd wprowadzający nowe treści (czynniki ryzyka zachorowania na rwę kulszową) przedstawia rysunek poniżej.

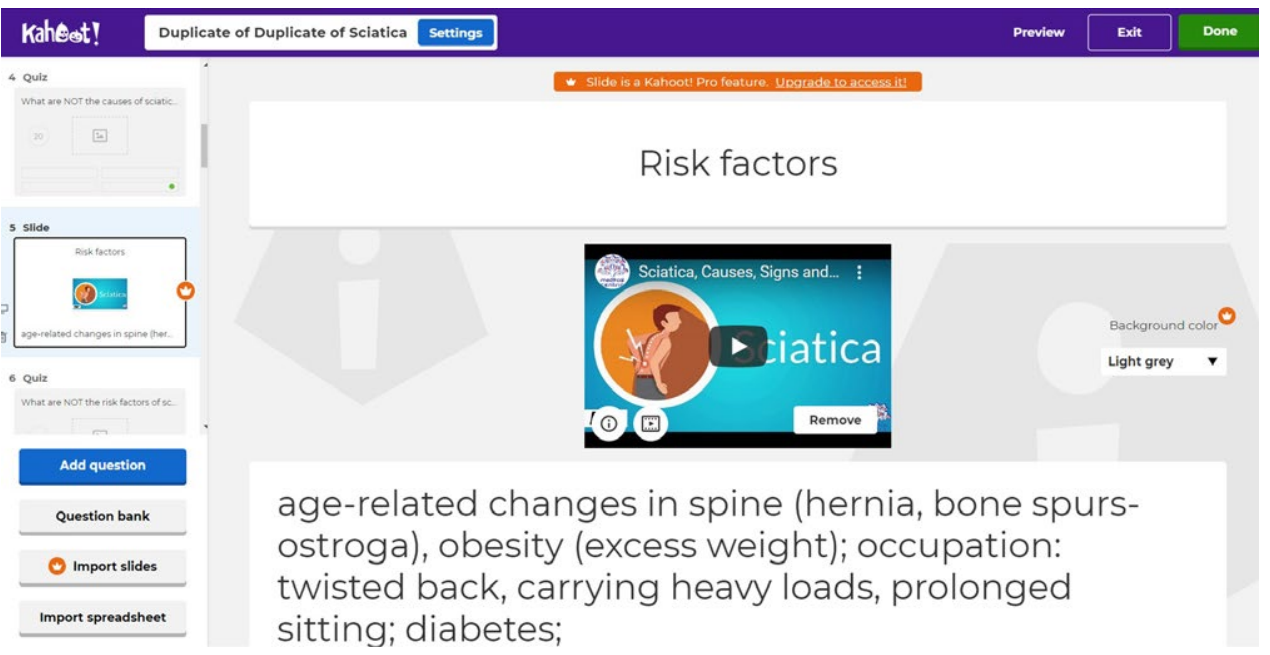

Rys. 1. Slajd z wbudowanym filmem wideo na platformie 'Kahoot'

Cały film², który trwa 5 minut i 24 sekundy, podzieliłam na kilka części (definicja, powody zachorowalności, czynniki ryzyka, diagnoza, leczenie itp.), które zostały już zasugerowane przez autorów tego filmiku; każda część trwała około 30 sekund. Po tej części wprowadzającej nowy temat, kolejne slajdy testowały zrozumienie materiału oraz stopień zapamiętania nowych słów i terminów.

QR code generator wykorzystywany był w celu generowania kodów, które umieszczałam w konspektach zajęć, co pozwalało na szyblkie przeniesienie studentów bezpośrednio do innych platform, np. z testami sprawdzającymi opanowanie wiedzy z danej lekcji.

Fiszkoteka. W celu zwiększenia efektywności nauki korzystałam również z aplikacji Fiszkoteka (https://fiszkoteka.pl). Ciekawą opcją tej platformy (wówczas dostępna ona była w wersji beta) jest możliwość tworzenia fiszek w sposób automatyczny. Z opcji tej korzystałam

2 Film widoczny na rysunku poniżej dostępny był pod adresem: https://www.youtube.com/watch?v=qIsyi6AwBts. 
w ten sposób, że wgrywałam istniejące już transkrypcje (napisy) do filmów na YT (napisy tworzone były również automatycznie przez YT), a na ich podstawie automatycznie tworzone były fiszki. Studenci odsyłani byli do systemu Fiszkoteka zanim wprowadzony był nowy materiał/ temat, zwykle wprowadzony był on poprzez wybrany przeze mnie film dostępny na YT (filmy te trwały od 3-5 minut). Miało to przygotować studentów do zadania (oglądania filmu wideo) oraz sprawić, aby postrzegali słówka z filmu jako już znane. Aktywność studentów w Fiszkotece była przeze mnie śledzona na bieżąco i odnotywana w dzienniku.

LearnClick. Aplikacja LearnClick (https://www.learnclick.com) umożliwia tworzenie kilku typów pytań w jednym teście, wykonywania testu wielokrotnie (liczbę możliwych powtórzeń określa nauczyciel) oraz ustawienia limitu czasu na rozwiązanie testu. Bardzo interesującą opcją systemu jest możliwość wygenerowania zbiorczych odpowiedzi całej grupy, co pokazywało procent prawidłowo udzielonych odpowiedzi wszystkich studentów z danej grupy, zwanej „klasą” (bez wyświetlania ich nazwisk) przy każdym pytaniu. Tworzenie „klas” z listą studentów i ich adresami mailowymi byłoby niezwykle czasochłonne, gdy prowadzi się zajęcia dla ponad 400 studentów, dlatego zautomatyzowałam tę czynność korzystając ze strony https://regex101.com.

Gap-filling generator ${ }^{3}$ to darmowa, prosta aplikacja tworząca teksty z lukami w różnej formie, np. usuwając całe wyrazy lub jedynie wybrane litery (np. tylko spółgłoski czy tylko samogłoski). Tworząc testy korzystałam z gotowych transkrypcji do filmów na YT lub tekstów wyszukanych w internecie. W sumie utworzyłam blisko 100 tekstów z lukami.

Sejda - W celu umożliwienia studentom wpisania odpowiedzi do testów generowanych przez gap-filling generator $\mathrm{w}$ rozszerzeniu pdf (bez konieczności ich drukowania i następnie skanowania wypełnionych plików) wyszukałam w internecie darmową aplikację do wypełnienia plików zapisanych w pdf „Sejda - edytor PDF online”, która dostępna jest pod adresem https://www.sejda.com/pl/pdf-editor.

Krzyżówki - okazjonalnie przygotowywałam również krzyżówki sprawdzające stopień przyswojenia terminologii z danego rozdziału podręcznika. Krzyżówki te tworzone były automatycznie przez aplikację komputerową dostępną w internecie (https://worksheets.theteacherscorner.net/).

WhatsApp jest to aplikacja na telefony (smartfony) i służyła mi jako komunikator umożliwiający szybki kontakt ze starostami poszczególnych grup, w celu przekazania pilnych ogłoszeń. Studenci najczęściej też tą drogą kierowali do mnie pytania i wątpliwości związane z oczekiwanym sposobem realizacji przez nich zadań.

YouTube Studio i OBS Studio. YT Studio to darmowa aplikacja umożliwiająca nagrywanie i montaż własnych filmów. Wadą YTS jest bardzo długi czas oczekiwania na możliwość edytowania nagranego filmu i stosunkowo mało precyzyjne przycinanie filmu podczas montażu. Z tych powodów, po kilku próbach prac z YTS, zdecydowałam się korzystać z OBS Studio (https://obsproject.com).

Wideokonferencje. Zajęcia synchroniczne miały głównie na celu przygotowanie studentów do krótkiego komponentu ustnego, obowiązującego na egzaminie końcowym z przedmiotu specjalistyczny język angielski. W trakcie zajęć zadawałam studentom pytania, nie przerywając im wypowiedzi robiłam notatki usłyszanych błędów (ang. delayed correction), które następnie omawiałam pod koniec zajęć z całą grupą, naturalnie bez informowania, kto te błędy popełnił.

https://www.johnsesl.com/generators/gapfill/gapfill.shtml 
Szczegółowe notatki dotyczące popełnianych błędów przez konkretnego studenta przesyłałam po zajęciach, kierując te uwagi bezpośrednio do studentów, których one dotyczyły, za pomocą czatu w MS Teams. Dało to taki efekt, że w trakcie egzaminów ustnych większość błędów popełnianych przez studentów została wyeliminowana.

Pecha Kucha to rodzaj prezentacji multimedialnej, który narodził się w Japonii. Polega on na przedstawieniu 20 slajdów, każdy po 20 sekund, co daje w sumie prezentację długości 6 minut i 40 sekund. Jest to zatem bardzo krótka forma prezentacji, którą wybrałam celowo po to, aby zaprezentowanie wybranego przez siebie tematu nie było zbyt stresujące dla studentów. Pecha Kucha miała zastąpić tradycyjną formę prezentacji multimedialnej, którą zwykle studenci przygotowywali na moich zajęciach raz na semestr w celu osiągnięcia jednego z efektów kształcenia (przygotowanie do wygłaszania referatów).

\section{3 / ANKIETY - WYNIKI BADAŃ}

\section{1 / Opis ankiet}

W trakcie prowadzenia nauczania zdalnego przeprowadziłam dwie ankiety wśród studentów czterech kierunków studiów prowadzonych przez CM UMK. Zajęcia ze specjalistycznego języka angielskiego z zakresu języka medycznego odbywały się na poziomie oscylującym wokół B2. Ankiety przeprowadzono dwukrotnie: po pierwszych zajęciach (w marcu 2020 r.; Ankieta I) oraz po ostatnich zajęciach (w czerwcu 2020 r.; Ankieta II3) w semestrze letnim. Skierowane one były do wszystkim studentów, z którymi prowadziłam zajęcia w semetrze letnim, tj. do 403 osób, z czego na pierwszą ankietę odpowiedziało 119 respondentów, a na drugą ankietę uzyskałam odpowiedzi od 124 osób, co stanowiło odpowiednio 29,53\% i 31\% ankietowanych. Mimo iż takie dane wyświetla aplikacja MS Teams, to jednak w przypadku niektórych pytań respondentów okazało się znacznie więcej, np. na pytanie $30 \mathrm{w}$ ankiecie czerwcowej (dotyczące tego, czy studenci planują korzystać z wprowadzonych aplikacji i platform po zakończeniu zajęć ze mna), respondentów było 177, a w wersji marcowej - 153. Ta niezgodność stanowi poważną przeszkodę w obliczeniach statystycznych. Prawdopodobnie wynikała z tego, że niektórzy studenci wypełniali ankietę więcej niż jeden raz.

Ankiety składały się z 33 pytań, z czego każda ankieta zawierała 27 pytań zamkniętych i 6 pytań otwartych. Z 33 pytań ankietowych 7 pytań składało się na tzw. metryczkę ankiety; dotyczyły one m.in. takich aspektów jak: płeć, kierunek studiów, dostęp do internetu i komputera, miejsca zamieszkania itp. Celem pierwszej ankiety było sprawdzenie poziomu wejściowego $\mathrm{z}$ zakresu ogólnie pojętych umiejętności korzystania $\mathrm{z}$ komputera $\mathrm{z}$ jednej strony oraz z drugiej - uzyskanie feedbacku na temat zaproponowanych przeze mnie form (metod, technik) nauczania w systemie zdalnym. Celem przeprowadzenia drugiej ankiety było natomiast sprawdzenie czy i ewentualnie na ile rozwinęły się umiejętności korzystania z komputerów i programów edukacyjnych przez studentów oraz uzyskanie informacji dotyczącej skuteczności i atrakcyjności prowadzonych przez cały semestr zajęć w formie zdalnej w zaproponowanej przeze mnie formie.

Pytania ankietowe tworzyły kilka grup pytań. Pierwszy blok dotyczył korzytania z aplikacji Teams. Studenci oceniali m.in. trafność wyboru takiej, a nie innej aplikacji, łatwości użytkowania tej aplikacji oraz tego czy znali ją już wcześniej. Drugi blok pytań odnosił się do procesu 
nauczania, sposobu prowadzenia zajęć w kontekście kształcenia zdalnego, ich skuteczności, atrakcyjności, zalet i wad e-learningu, treści zajęć, doboru oraz układu treści zaproponowanych w obrębie Zespołu i trudności technicznych towarzyszących zdobywaniu wiedzy. Ponieważ oprócz MS Teams wprowadziłam też szereg innych aplikacji wspierających nauczanie, pojawiło się też pytanie dotyczące oceny wyboru pozostałych aplikacji/platform/systemów. Trzeci blok pytań dotyczył studentów, zwłaszcza czasu, który musieli poświęcić na e-learning z prowadzonego przeze przedmiotu medycznego języka specjalistycznego, wyjaśniając powody spędzania określonego czasu, omówienia radzenia sobie z ewentualnymi problemami wynikającymi z poziomu merytycznego zajęć czy z formy samych zadań udostępnianych na różnych platformach. Czwarty blok pytań dotyczył prowadzącej, a konkretnie formy i jakości kontaktu z prowadzącą zajęcia, kanałów kontaktu oraz efektywności komunikacji. Ostatnie pytania $\mathrm{w}$ ankiecie rozszerzały perspektywę i dotyczyły nauczania zdalnego jako takiego, oceny wad i zalet e-learningu w szkolnictwie wyższych itp.

\section{2 / Informacje wstępne}

O wypełnienie ankiety poprosiłam siedem grup reprezentujących cztery różne kierunki studiów („lekarski”, „optometria”, „fizjoterapia”, „terapia zajęciowa”), z czego dwie grupy stanowili studenci niestacjonarni („fizjoterapia”, „terapia zajęciowa”), a trzy z nich kształciły się na studiach magisterskich („fizjoterapia” na studiach stacjonarnych i niestacjonarnych, „optometria"). W drugiej ankiecie (Ankieta II) organizowanej pod koniec semestru odpowiedzi nie udzielili studenci na kierunku „fizjoterapia” na studiach niestacjonarnych (studenci kończyli kurs w kwietniu) oraz studenci II roku kierunku „terapia zajęciowa”. Widoczny natomiast jest wzrost odpowiedzi udzielonych przez studentów II roku kierunku lekarskiego.

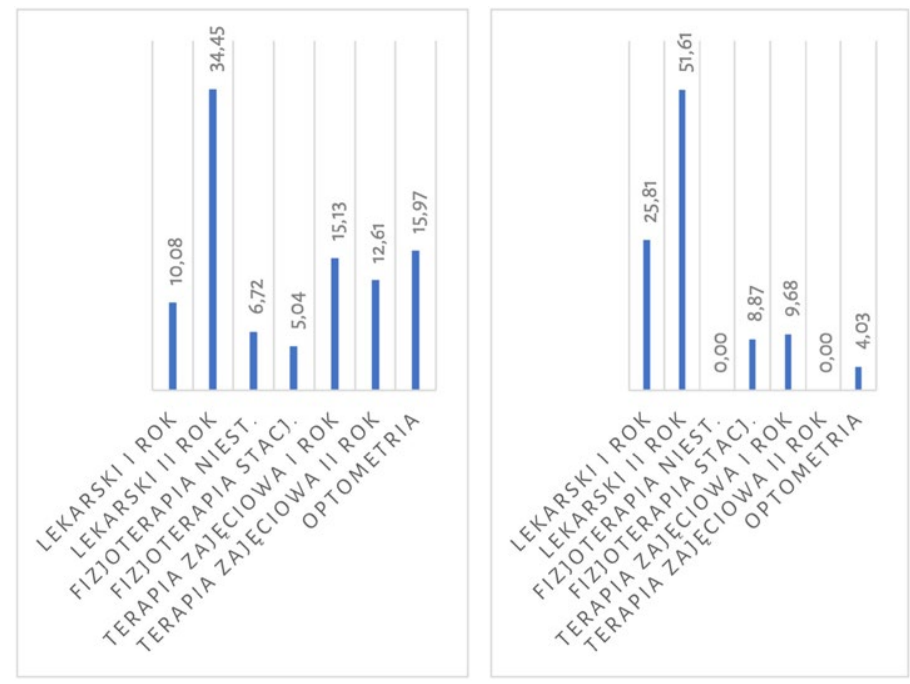

Rys. 2. Procent liczby ankietowanych wedłu kierunku studiów

W obu ankietach uczestniczyło ok. 40\% studentów zamieszkujących wieś i ok. 40\% zamieszkujących duże miasta (powyżej 200 tys. mieszkańców). W pierwszej ankiecie wzięło udział 88\% kobiet i 12\% mężczyzn, a w drugiej ankiecie odpowiednio 69\% i 31\%. Dysproporcje te generalnie 
odzwierciedlają rozkład płci na kierunkach, które brały udział w ankietach. Swobodny dostęp do internetu (przez całą dobę) lub do 8 godzin dziennie deklarowało 94\% respondentów w Ankiecie I i $98 \%$ w Ankiecie II. Wynika z tego, że ogólnie rzecz biorąc prawie wszyscy ankietowanych mieli swobodny dostęp do internetu przez kilka godzin dziennie. Interesujące jest to, że aż 93\% respondentów w obu ankietach korzystało z internetu dostępnego z telefonu komórkowego.

Wybór aplikacji MS Teams jako wiodącej platformy edukacyjnej zdobył zwolenników po zakończeniu kursu. Mimo nielicznych krytycznych uwag dotyczących MS Teams (nawet już po całym semestrze jego użytkowania) na początku nauczania zdalnego ostatecznie $73 \%$ uznało MS Teams, jako dobry wybór systemu do kształcenia na odległość, a pod koniec semestru aż $92,7 \%$. Ten rozkład ocen ilustruje poniższy wykres:

9. Jak ocenia Pan/i wybór Microsoft Teams, jako narzędzia do nauki zdalnej Wiẹcejszczegółón

dobry wybór, świetna aplikacja $\quad 87$

zły wybór, nie podoba mi siẹ t... 32

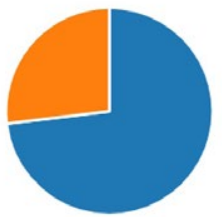

9. Jak ocenia Pan/i wybór Microsoft Teams, jako narzędzia do nauki zdalnej Więcej szczegółów

dobry wybór, świetna aplikacja $\quad 115$

zły wybór, nie podoba mi się t... 9

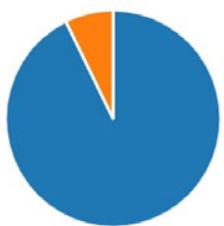

Rys. 3. Ocena MS Teams w ankiecie marcowej (rys. na górze) i w ankiecie czerwcowej (rys. na dole)

\section{3 / Ocena procesu nauczania i kwestii technicznych}

Wykresy poniżej wskazują na to, że w początkowej fazie studenci oceniali atrakcyjność moich zajęć w przeważającej większości średnio lub wysoko (w sumie 83,2\%), z czego wysoko oceniło zajęcia tylko $10,1 \%$ respondentów. Słabo i bardzo nisko w sumie oceniło zajęcia $6,7 \%$ ankietowanych. Po zakończeniu nauczania zdalnego studenci oszacowali zajęcia w przeważającej większości wysoko i bardzo wysoko (81,5\%), tylko 16,1\% osób uznało je za „średnie”, a ocena „bardzo nisko" w ogóle nie wystąpiła.

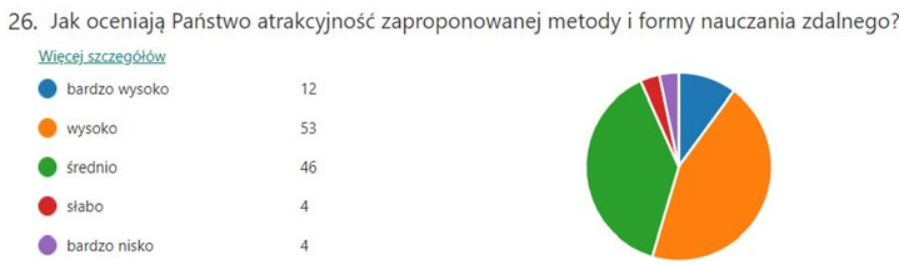




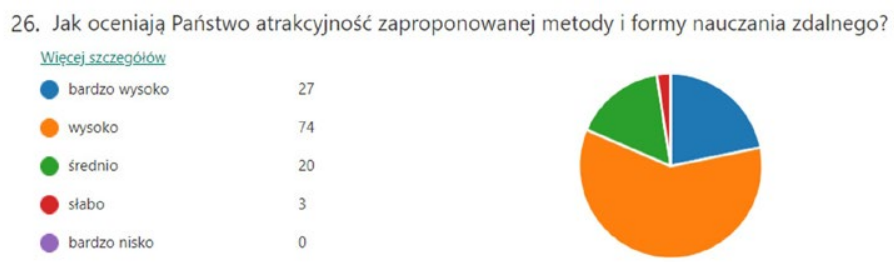

Rys. 4. Ocena atrakcyjności e-learningu w ankiecie marcowej (rys. na górze) i w ankiecie czerwcowej (rys. na dole)

W marcu ocenę skuteczności moich zajęć studenci określili na 32,7\%, natomiast w czerwcu ocena ta wzrosła do 45,2\%. Odpowiedź „bardzo skuteczny, ale ,w klasie’ jest skuteczniejszy” zyskała poparcie $22,2 \% \mathrm{w}$ marcu i $31,7 \% \mathrm{w}$ czerwcu. Co ciekawe, $11,8 \%$ ankietowanych w marcu i $2,4 \%$ w czerwcu mimo iż oceniło nauczanie zdalne jako „słabe” to jednak uznało je za „bardziej skuteczne niż w klasie”. 25,2\% respondentów oceniło e-learning jako „średni” w marcu i 17,9\% w czerwcu. Widać zatem, że studenci zadowoleni byli ze skuteczności nauczania zdalnego, jednak dość duża grupa osób wolałaby mieć zajęcia w tradycyjny sposób. W stosunku do początku zajęć zdalnych można zaobserwować ogólną tendencję wzrostową w pozytywnych ocenach prowadzonego przeze mnie e-learningu.

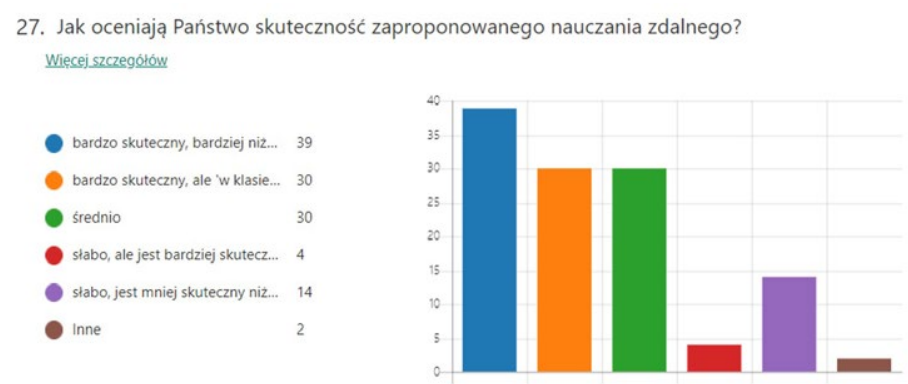

27. Jak oceniają Państwo skuteczność zaproponowanego nauczania zdalnego?
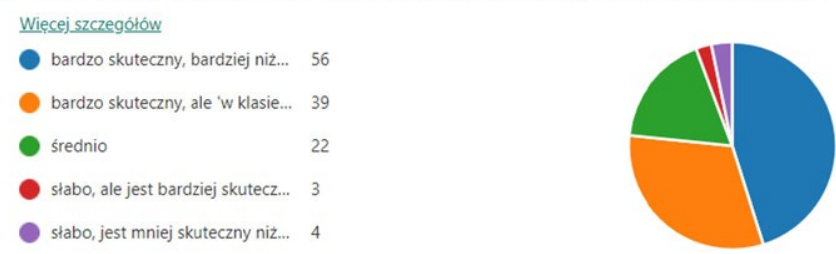

Rys. 5. Ocena skuteczności e-learningu w ankiecie marcowej (rys. na górze) i w ankiecie czerwcowej (rys. na dole)

Studenci proszeni byli o wypowiedzenie się na temat struktury Zespołu. Najmniej podobał się w strukturze Zespołu zaproponowany przeze mnie na początku semestru układ kanałów, jak rónież zakładka ,Pin Board' (z tego względu zrezygnowałam z prowadzenia tej zakładki, grupy mogły jednak same aktualizować dane na tablicy ogłoszeń) oraz format konspektów wgrywanych przeze mnie co tydzień do MS Teams. 
14. Jeśli odpowiedź na pytanie 12 brzmiało 'podoba mi się układ MS Teams', proszę uszczegółowić, co się Państwu najbardziej podoba Wiecej.jszczegótón
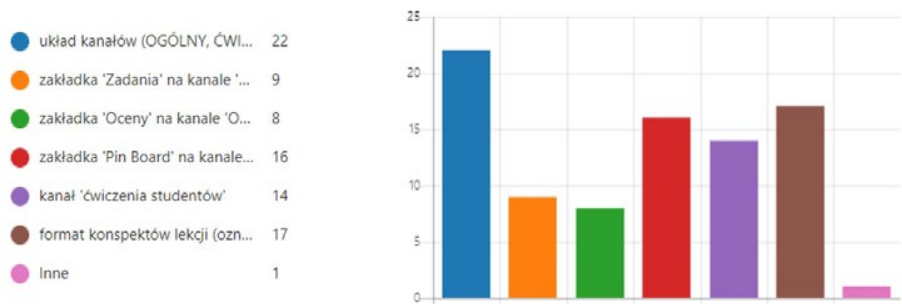

14. Jeśli odpowiedź na pytanie 12 brzmiało 'podoba mi się układ MS Teams', proszę uszczegółowić, co się Państwu najbardziej podoba Więçejszczegótón
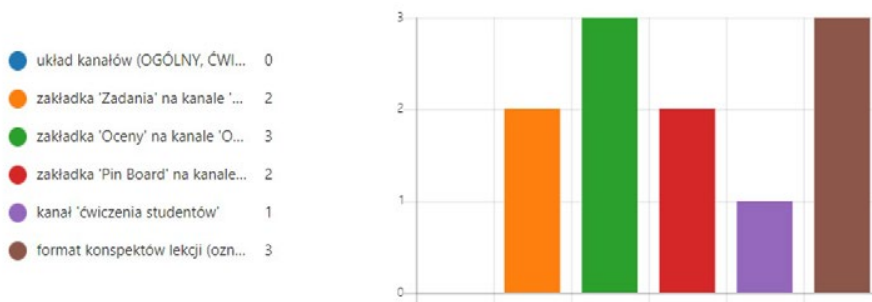

Rys. 6. Najwyżej oceniane elementy struktury Zespołu na MS Teams w ankiecie marcowej (rys. na górze) i w ankiecie czerwcowej (rys. na dole)

Ogólnie struktura Zespołów jednak podobała się prawie 66\% studentów w Ankiecie I i ponad $69 \%$ studentów w Ankiecie II. Na początku semestru studentom podobała się nie tylko struktura Zespołu w MS Teams (układ kanałów), format opracowywanych przeze mnie konspektów oraz zakładka z ,tablicą korkową, ale także kanał ,ćwiczenia studentów', w którym studenci wgrywali swoje prace domowe. Pod koniec semestru nikt $\mathrm{z}$ ankietowanych nie wypowiedział się na temat układu kanałów, na popularności natomiast zyskały karty ,Oceny' (punkty z testów na MS Forms zintegrowane z MS Teams) i ,Zadania' (lista testów do wykonania) na kanale ,Ogólnym'; stracił na popularności z kolei kanał ,ćwiczenia studentów'. Dużym uznaniem cieszyły się też treści i ich układ prezentowane w konspektach lekcji.

Jeśli chodzi o ocenę struktury strony po zakończeniu semestru, to widać zasadnicze różnice w stosunku do odpowiedzi z początku semestru: na popularności zyskała ,Tablica korkowa’ (niektóre grupy prowadzily je same), karta ,Oceny' i ,Zadania', a także w mniejszym stopniu kanał ,ćwiczenia studentów'. Spadła natomiast ogólna opinia o układzie kanałów pod koniec semestru w stosunku do zajęć z początku nauczania zdalnego. Należy jednak zauważyć, że $\mathrm{w}$ ankiecie czerwcowej znacznie mniej studentów wypowiedziało się na temat tego, co im się podobało w układzie strony. 
13. Jeśli odpowiedź na pytanie 12 brzmiało 'nie podoba mi się' proszę zaznaczyć, co konkretnie nie podoba się Państwu.

Wiecejs szczegótón
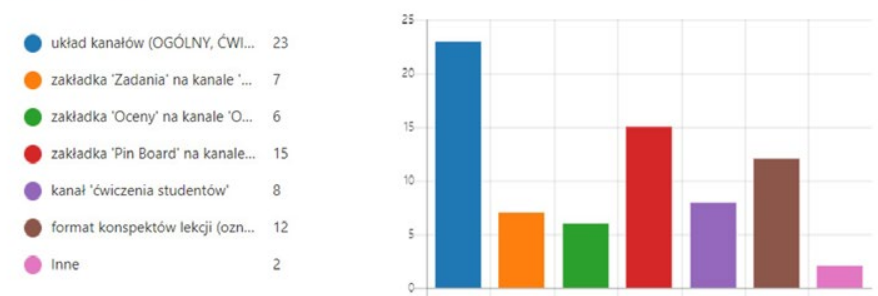

13. Jeśli odpowiedź na pytanie 12 brzmiało 'nie podoba mi się' proszę zaznaczyć, co konkretnie nie podoba się Państwu.

Wiecejszcregotón
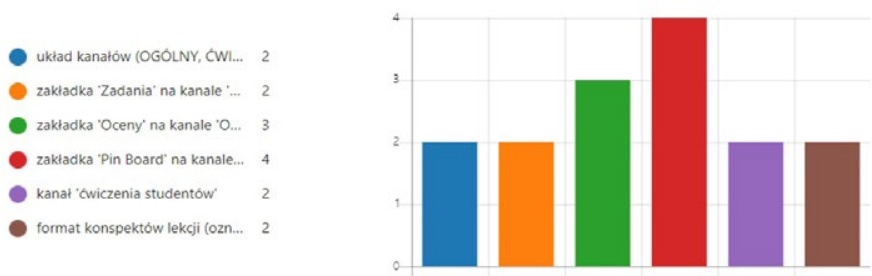

Rys. 7. Najniżej oceniane elementy struktury Zespołu na MS Teams w ankiecie marcowej (rys. na górze) i w ankiecie czerwcowej (rys. na dole)

Podobnie jak w przypadku poprzedniego pytania, w ankiecie czerwcowej znacznie mniej studentów wypowiedziało się na temat tego, co im się nie podobało w układzie strony. Weryfikacja efektów uczenia się, która najbardziej przypadła studentom do gustu to zdecydowanie platforma Kahoot, zarówno w ankiecie marcowej, jak i czerwcowej. Wzrosto zainteresowanie sprawdzaniem wiedzy za pomocą aplikacji MS Forms, a spadło aplikacją Fiszkoteka, filmami wideo dotyczącymi gramatyki (co zrozumiałe, bowiem studenci po wielokrotnych powtórkach z gramatyki trwającymi cały semestr nie mieli już potrzeby słuchania objaśnień gramatycznych) oraz krzyżówkami. Zmniejszyła się też liczba odpowiedzi „żadna [forma weryfikacji efektów uczenia się nie jest dla mnie motywująca], nie lubię nauczania zdalnego".

19. Która forma weryfikacji efektów uczenia się (sprawdzania opanowania materiału) jest dla Państwa najbardziej motywująca?
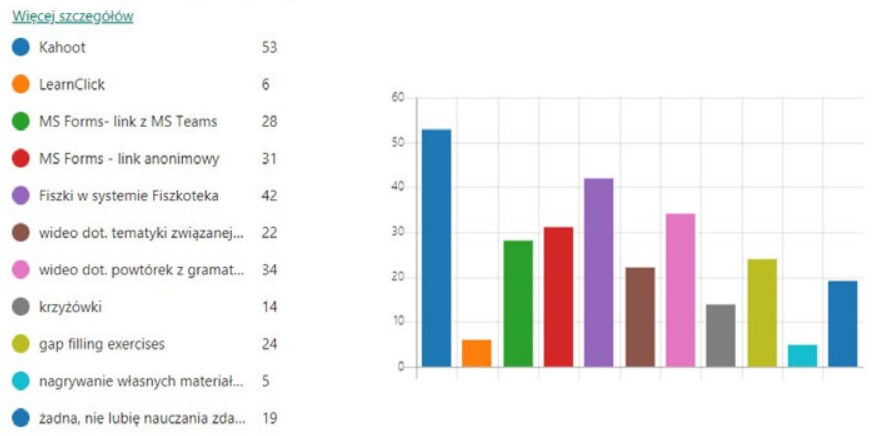
19. Która forma weryfikacji efektów uczenia się (sprawdzania opanowania materiału) jest dla Państwa najbardziej motywująca?

\begin{tabular}{lc} 
Więcejszczegótów & \\
\hline Kahoot & 65 \\
LearnClick & 7 \\
MS Forms- link z MS Teams & 57 \\
MS Forms - link anonimowy & 57 \\
Fiszki w systemie Fiszkoteka & 28 \\
wideo dot. tematyki związanej... & 27 \\
kideo dot. powtórek z gramat... & 34 \\
grzyzónki filling exercises & 12 \\
nagrywanie własnych materiał... & 6 \\
\hline zadna, nie lubię nauczania zda.... & 9 \\
\hline wideokonferencja & 19
\end{tabular}

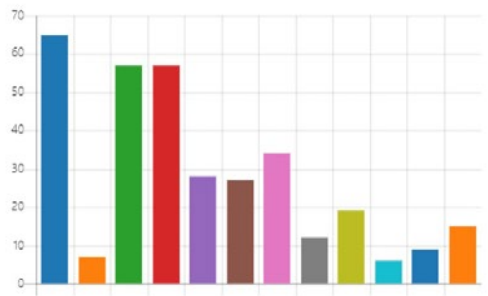

Rys. 8. Najbardziej motywujące formy weryfikacji efektów uczenia się według ankiety marcowej (na górze) i czerwcowej (na dole).

Interesujące jest to, że testy na platformie Kahoot zyskały sobie tylu zwolenników, mimo iż postrzegane były jako bardzo stresujące nieprzerwanie przez cały semestr. Po semestrze letnim wyraźnie zwiększyła się liczba respondentów, dla których żadna forma e-learningu nie była już stresująca. W związku z wprowadzeniem zajęć w formie synchronicznym pod koniec semestru, forma wideokonferencji pojawiła się dodatkowo w Ankiecie II. Dla wielu studentów była to bardzo stresująca forma pracy.

20. Która forma weryfikacji efektów uczenia się (sprawdzania opanowania materiału) jest dla Państwa najbardziej stresująca?

Wiẹcejszczegótów

Kahoot 45

LearnClick 31

MS Forms- link z MS Teams 27

- MS Forms- link anonimowy 7

wideo dot. tematyki związanej... 6

wideo dot. powtórek $z$ gramat... 5

krzyzówki

gap filling exercises $\quad 14$

nagrywanie wasnych materiał... 73

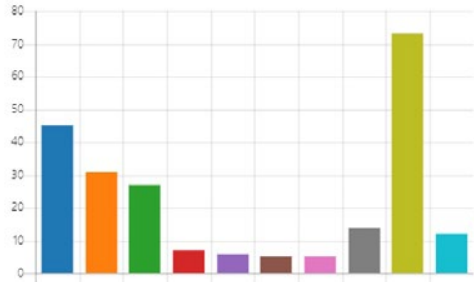

zadna mnie nie stresuje, taka f... 12

20. Która forma weryfikacji efektów uczenia się (sprawdzania opanowania materiału) jest dla Państwa najbardziej stresująca?

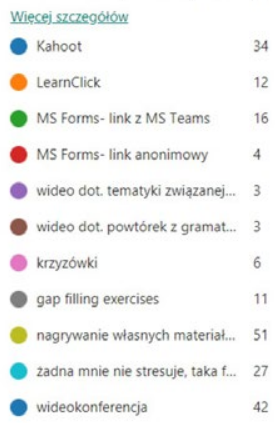

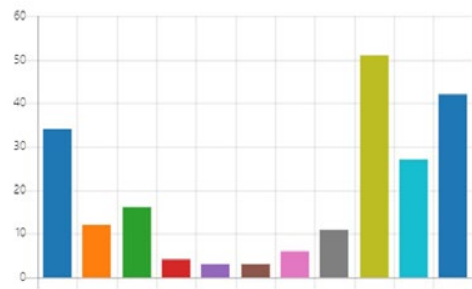

Rys. 9. Najbardziej stresujące formy weryfikacji efektów uczenia się według ankiety marcowej (na górze) i czerwcowej (na dole). 
Kolejne pytanie ankietowe dotyczyło czasu spędzanego zwykle przed komputerem w celu realizacji zadań. Okazało się, że 6,7\% studentów potrzebowało zaledwie 1 godziny w tygodniu pracy $\mathrm{z}$ komputerem $\mathrm{w}$ celu wykonania prac domowych, 63\% ankietowanych potrzebowało średnio od 2 do 5 godzin pracy, a 19,3\% od 6 do 10 godzin na początku semestru, natomiast pod koniec zajęć zdalnych liczba ta zmieniła się i wynosiła już odpowiednio $21 \%$ dla osób spędzających ok. 1 godziny przed komputerem, $64,5 \%$ dla przedziału $2-5$ godzin i tylko $8,9 \%$ dla przedziału 6-10 godzin.
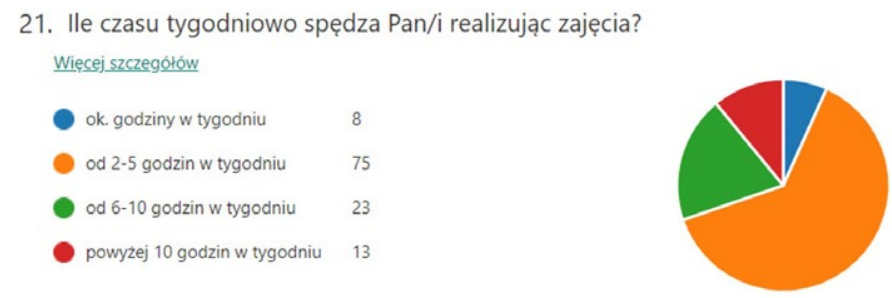

21. Ile czasu tygodniowo spędza Pan/i realizując zajęcia?

$\begin{array}{ll}\text { Wieccej szczegółów } \\ \text { ok. godziny w tygodniu } & 26 \\ \text { od } 2-5 \text { godzin w tygodniu } & 80 \\ \text { od } 6.10 \text { godzin w tygodniu } & 11 \\ \text { powyzej } 10 \text { godzin w tygodniu } & 7\end{array}$

Rys. 10. Liczba godzin w tygodniu poświęconych na realizację asynchronicznych zajęć online według ankiety marcowej (na górze) i czerwcowej (na dole)

Jak można wywnioskować z odpowiedzi na pytanie 23, czas poświęcony na realizację materiału z zajęć (w 44\% w Ankiecie I i w 65,3\% w Ankiecie II) wynika z tego, że student wykonuje niektóre ćwiczenia wielokrotnie (np. fiszki, Kahoot, oglądanie filmów wideo itd.), bo jest to dla niego ciekawy sposób uczenia się. Pozostałe odpowiedzi dotyczyły wykonywania tylko tego co konieczne i wychodzenie z systemu z uwagi na to, że nauczanie zdalne zupełnie nie odpowiadało respondentom. Wydaje się zatem, uwzględniając powyższy wzrost wyniku o ok. 20\%, że zaproponowana forma nauczania zmotywowała studentów do nauki.

Nie można nie wspomnieć o szeregu problemach, które studenci zgłaszali, których nie byłam w stanie rozwiazać, zarówno technicznych, jak i „życiowych”. Problemy techniczne polegały na tym, że nie mieli oni stosownego sprzętu (zwykle komputerów, ale też mikrofonów czy kamer internetowych), mieli małą przepustowość internetu lub słaby zasięg, w związku z tym nie zawsze mogli uczestniczyć w zajęciach lub uczestniczyli w nich biernie.

\section{4 / Samoocena studentów}

Na początku nauczania zdalnego (Ankieta I) niespełna 74\% studentów oceniło swoje umiejętności nawigacji po MS Teams na poziomie bardzo dobrym lub dobrym, mimo iż $98,3 \%$ respondentów nie znała tej aplikacji wcześniej, co sugeruje, iż korzystanie z niej jest dla studentów raczej intuicyjne i w większości przypadków nie ma potrzeby organizowania szkoleń z tego zakresu. 
Liczba dotycząca oceny umiejętności korzystania z MS Teams wzrosła jeszcze pod koniec semestru z 74\% do $91 \%$. Podczas gdy $73 \%$ studentów stwierdziło na początku kursu, że wprowadzenie MS Teams do nauki zdalnej było dobrym wyborem, pod koniec semestru wartość ta zwiększyła się do 92,7\%.

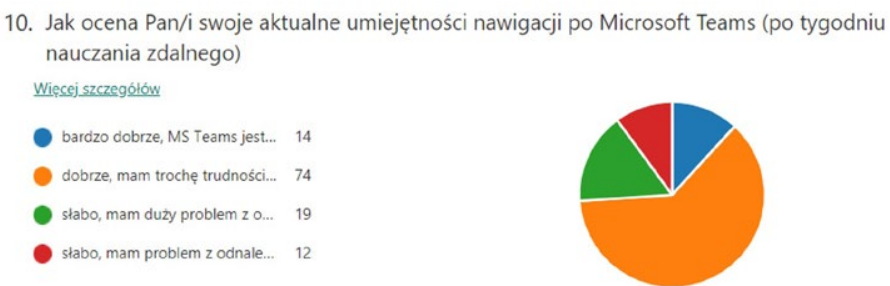

10. Jak ocena Pan/i swoje aktualne umiejętności nawigacji po Microsoft Teams (po semestrze nauczania zdalnego) Wiecejszczegóón

bardzo dobrze, MS Teams jest... 54

dobrze, mam trochẹ trudności... 59

- słabo, mam duzy problem z o... 7

słabo, mam problem $z$ odnale... 4

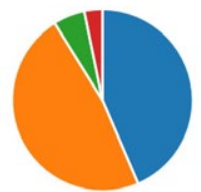

Rys. 11. Ocena umiejętności korzystania z MS Teams w ankiecie marcowej (a górze) i czerwcowej (na dole)

61,4\% studentów radziło sobie bardzo dobrze lub dobrze z obsługą komputera i nawigacją po internecie po pierwszych zajęciach zdalnych, a $78 \%$ po ostatnich zajęciach. Jedynie $3,4 \%$ studentów na początku e-learningu i o,8\% pod koniec semestru deklarowało, że słabo sobie radzi, zatem ogólny poziom umiejętności IT był wysoki już na początku nauczania zdalnego. Oprócz umiejętności technicznych, studenci wyrażali opinie (różnymi kanałami komunikacji) o swoich postępach merytorycznych, w szczególności w odniesieniu do umiejętności rozumienia ze słuchu, znajomości gramatyki oraz poszerzeniu słownictwa.

Materiały z gramatyki $\mathrm{w}$ zamierzeniu miały stanowić jedynie dodatek do zajęć i miały być realizowane niejako w tle, poprzez pracę własną studentów (tylko tych studentów, którzy uznali, że potrzebują powtórek z gramatyki języka angielskiego). Oprócz nagranych filmów na YT, napisałam również ponad 100 pytań testowych na MS Forms, które pozwalały przećwiczyć zagadnienia omawiane na filmach na YT. Ogólnie filmy wyjaśniające gramatykę było ocenione bardzo pozytywnie: „Tyle lat uczę się angielskiego, ale dopiero po obejrzeniu filmików z gramatyką które pani dla nas przygotowuje mam wrażenie że poraz pierwszy rozumiem czasy angielskie” (A2-7), „Bardzo fajnie wytlumaczone zagadnienia z gramatyki, dzięki przesłanym filmom czuje, że dużo zagadnień zrozumiatem po raz pierwszy." (Az-8).

\section{5 / Ocena prowadzącej}

Jednym z aspektów oceny nauczyciela była jakość kontaktu. Studenci uznali na początku semestru, że kontakt jest bardzo dobry, wiadomości zwrotne studenci otrzymują bardzo szybko i są one pomocne, a za najlepszy kanał kontaktu uznali przekazywanie informacji poprzez starostów grup (tj. poprzez WhatsApp), w drugiej kolejności poprzez chat na MS Teams. 
15. Który sposób kontaktu z wykładowcą Państwu odpowiada? Wiẹcejszczegółów
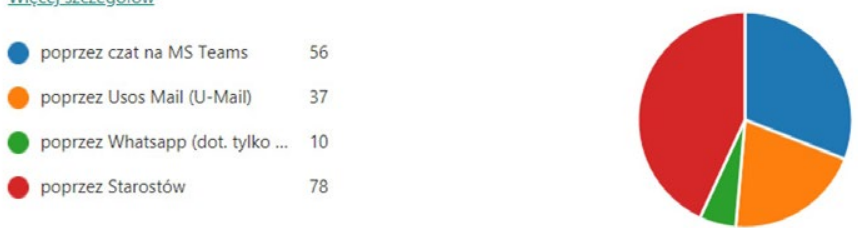

15. Który sposób kontaktu z wykładowcą Państwu odpowiadał?

$\begin{array}{lr}\text { Wiecej_szczegółów } \\ \text { poprzez czat na MS Teams } & 84 \\ \text { poprzez Usos Mail (U-Mail) } & 16 \\ \text { poprzez Whatsapp (dot. tylko ... } & 11 \\ \text { poprzez Starostów } & 75\end{array}$

Rys. 12. Ocena formy kontaktu z nauczycielem w ankiecie marcowej (na górze) i czerwcowej (na dole)

Po semestrze letnim preferencje studentów są bardzo podobne. Studenci wysoko też oceniają kontakt bezpośrednio z wykładowcą poprzez czat, co mogło wynikać z tego, że na wiadomości (na czacie, poprzez mail i WhatsApp) odpowiadałam codziennie; było to istotne zwłaszcza na początku nauczania zdalnego, kiedy pojawiało się bardzo dużo pytań natury technicznej.

16. Jak oceniają Państwo kontakt z prowadzącą?

Więçejszczegółów

jest bardzo dobry, odpowiedzi... 92

jest dobry, odpowiedzi otrzym... 25

jest zły, brak kontaktu z prowa... 2

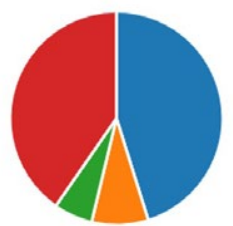

\footnotetext{
jest zły, brak kontaktu z prowa... 2
}

16. Jak oceniają Państwo kontakt z prowadzącą?
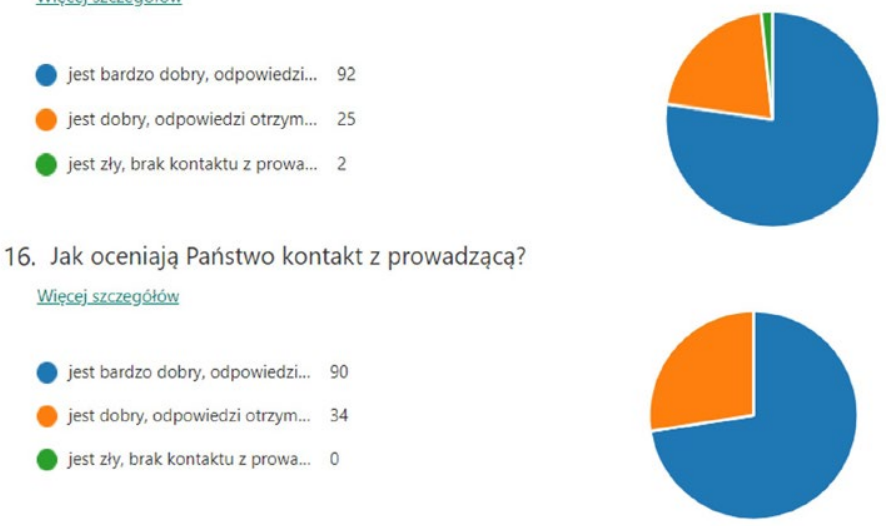

Rys. 13. Ocena kontaktu z nauczycielem w ankiecie marcowej (na górze) i czerwcowej (na dole)

Jeśli chodzi o materiały przygotowane przeze mnie to studenci wypowiadali się bardzo pozytywnie. Na pytanie 25 - „Jakich trudności merytorycznych doświadcza Pan/i w trakcie realizacji nauczania zdalnego (związanych z treścią materiałów dydaktycznych)" wpisano 85 odpowiedzi w Ankiecie I i 55 odpowiedzi w Ankiecie II, z czego prawie wszystkie zawierały informacje typu „Brak" lub szereg uwag pochlebnych: „Zaangażowanie w pracę zdalna ze strony prowadzacego by to na 110\%.” (A2-25), „Fajnie, że Pani się tak stara i nagrywa te filmiki, bo jak na razie jest Pani jedyna prowadzacca, która nadrabia z nami materiat i jest to super :)” (A1-28), „Zajęcia zdalne z jezzyka angielskiego sa. 
najlepiej przygotowana forma zajęć zdalnych. Główna uwaga jest taka, że przedmioty wiodące na kierunku mogtyby obrać podobna strategię." (A2-27).

Pojawiły się też oczywiście uwagi krytyczne, były to jednak pojedyncze wypowiedzi. Można z nich wywnioskować, że ich autorzy byli na poziomie poniżej wymaganego „na wejściu” B1, co tłumaczyłoby konieczność poświęcania nieproporcjonalnie dużej ilości czasu na prowadzony przeze mnie przedmiot. Kwestia nauczania języków obcych w szkołach wyższych absolwentów szkół średnich niebędących na wymaganym poziomie B1 jest problemem ogólnopolskim. Ważne jest, że w Ankiecie II niemal wszystkie uwagi krytyczne zostały zniwelowane, zatem wynikały one przede wszystkim ze zderzenia się z czymś nowym, wcześniej nieznanym.

\section{6 / Ocena e-learningu}

Dwa pytania w ankietach dotyczyły wad i zalet e-learningu jako formy nauczania. Respondenci podkreślali elastyczność pracy, jaką daje kształcenie w systemie zdalnym i możliwość indywidualizacji nauki. W szczególności studenci doceniali możliwość decydowania o godzinach i o tempie nauki, stały dostęp do materiałów dydaktycznych, a także oszczędność czasu wynikającą z braku konieczności dojechania na uczelnię. Przewija się też wątek możliwości samodecydowania o swojej nauce. Oto kilka cytatów: „Szybka komunikacja i możliwość dostosowania czasu pracy tylko do siebie zamiast do grupy” (A2-12), „Więcej czasu na nauke, co zwiazane jest z bokiem konieczności dojazdu na zajęcia z Fordonu, w którym mieszkam na codzień” (A2-17), „Możliwość powtórek kiedy to potrzebne, można się uczyć ile kto potrzebuje (np. gramatyka, inni potrzebuja więcej, inni mniej czasu)."(A2-59).

Poczucie odpowiedzialności za własną naukę, w duchu konstruktywistycznym, również wybrzmiewało w wielu uwagach studentów, np. „Rozwiązywanie zadań i quizów wymaga ode mnie samodzielnej pracy i myślę, że dzięki temu zapamiętam więcej słownictwa oraz zasad gramatyki." (A1-100).

Nauczanie zdalnie spodobało się na tyle, że na pytanie ankietowe (nr 30) czy studenci planują korzystać z platform i aplikacji wprowadzonych do e-learningu po zakończeniu nauczania zdalnego na moich zajęciach, 59\% studentów zdeklarowało „tak” w marcu i 70,6\% w czerwcu. Wydaje się, że dało mi się zmotywować studentów do nauki, podjętej z własnej inicjatywy, co było jednym z założeń konstruktywistycznych przyjętych w moim nauczaniu zdalnym.

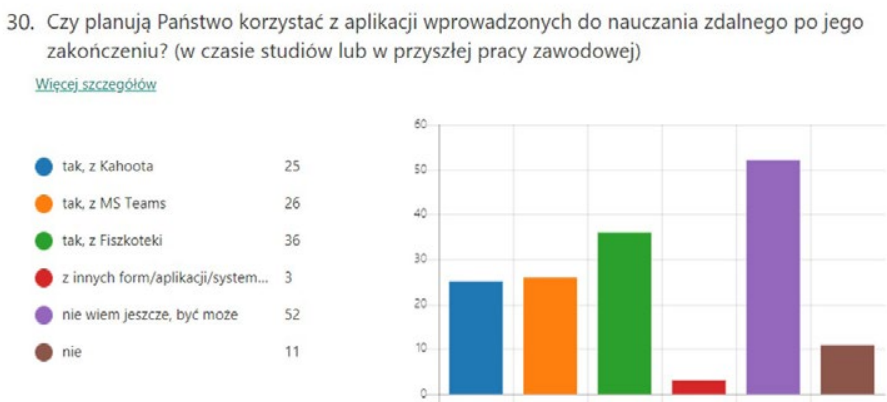


30. Czy planują Państwo korzystać z aplikacji wprowadzonych do nauczania zdalnego po jego zakończeniu? (w czasie studiów lub w przyszłej pracy zawodowej)

Wiesejszczegotow
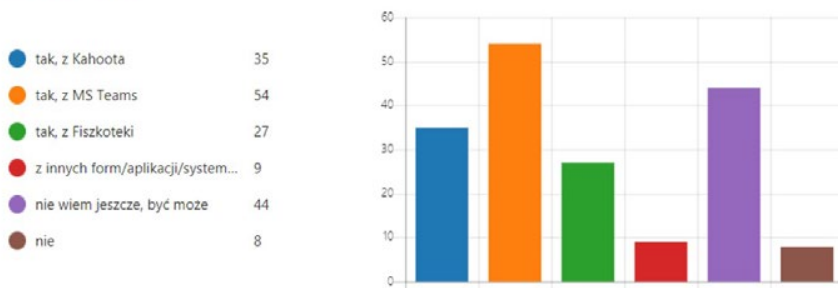

Rys. 14. Prawdopodobieństwo korzystania z platform używanych podczas e-learningu po zakończeniu nauczania zdalnege w ankiecie marcowej (na górze) i czerwcowej (na dole)

Jeśli chodzi o wady nauczania zdalnego to główną wadą powtarzającą sie w obu ankietach był „brak kontaktu w cztery oczy z prowadzacym”. (A1-1).

\section{4 / PODSUMOWANIE}

Ogólnie rzecz biorąc, mimo początkowych problemów technicznych, nauczanie zdalne, które zaproponowałam moim studentom w zdecydowanej większości przypadków zostało przez nich ocenione pozytywnie, często wręcz entuzjastycznie, uznane za atrakcyjne, skuteczne i motywujące. Studenci w przeważającej większości doceniali moje wysiłki zmierzające do zachęcania ich do wielokrotnych powtórek z własnej inicjatywy (samokontrola, samoregulacja) oraz do uatrakcyjnienia formy wprowadzanego nowego materiału (ogólnie do tworzenia środowiska sprzyjającego uczeniu się i do budowania „rusztowania”), co było również dla mnie bardzo motywujące. Założenia konstruktywistyczne, które stanowiły podstawy zaproponowanego e-learningu zostały zrealizowane poprzez stosowanie samokontroli i samoregulacj przez studentów oraz przez tworzenie środowiska edukacyjnego przez prowadzącą, które promowało inicjowanie i podtrzymywania motywacji do uczenia.

\section{5 / WNIOSKI KOŃCOWE}

Patrząc na e-learning z szerszej perspektywy trzeba też wspomnieć, że pandemia spowodowała gwałtowny rozwój umiejętności obsługi komputera i niektórych e-learningowych programów edukacyjnych u nauczycieli pracujących w szkolnictwie wyższym. Uwzględniając choćby tylko moje doświadczenia, oprócz platformy Kahoot i Fiszkoteki, wszystkie pozostałe platformy i aplikacje były mi wcześniej nieznane, a nagrywanie filmów na YT i ich „postprodukcja” były moim debiutem. Potrzeba zatem zrodziła pomysły i konieczność przejścia przez przyspieszone samodoszkalanie z zakresu zastosowania komputerów w edukacji, co w ostatecznym rozrachunku dało wymierny efekt dodany, spowodowało bowiem szybki rozwój kompetencji IT wśród kadry uniwersyteckiej. 


\section{E-LEARNING IN TEACHING MEDICAL ENGLISH}

SUMMARY The study has shown that the most motivating form of activities for the students (in both surveys) was Kahoot platform, although it was also assessed as one of the most stressful activities (along with audio-recording students' projects in Power Point). In the surveys, the majority of respondents evaluated the Teams-based course of medical English very positively, both in terms of learning the course content and in enhancing their computer skills. The results of the surveys demonstrate that a vast number of students who took part in the online course of medical English were satisfied with this form of learning, which they found effective, motivating and attractive.

\section{E-LEARNING W NAUCZANIU MEDYCZNEGO JĘZYKA ANGIELSKIEGO}

STRESZCZENIE Celem niniejszego artykułu jest opisanie metod i form e-learningu wprowadzonych w semestrze letnim 2020 r. w Uniwersytecie Mikołaja Kopernika w Toruniu na zajęciach $\mathrm{z}$ medycznego języka angielskiego prowadzonych dla poskich studentów. Zastosowany e-learning opierał się na podstawach teoretycznych konstruktywizmu. W artykule omawiane są również wyniki dwóch anonimowych ankiet, przeprowadzonych wśród studentów Collegium Medicum UMK, które dotyczyły zajęć z medycznego języka angielskiego. Pierwsza ankieta przeprowadzona została po tygodniu zajęć prowadzonych $\mathrm{w}$ formie e-learningu (w marcu), a druga po zakończonych zajęciach nauczania na odległość (w czerwcu). W każdej ankiecie brało udział ponad stu respondentów. W opisanym nauczaniu zdalnym używano wielu aplikacji, m.in. MS Teams, MS Forms, Fiszkoteka, Kahoot, LearnClick, OBS Studio, YouTube itp. Z przeprowadzonych ankiet wynika, że dla zdecydowanej większości studentów uczestniczących w zajęciach zdalnych ze specjalistycznego języka angielskiego e-learning był bardzo pozytywnym doświadczeniem, które okazało się skuteczną, motywującą i atrakcyjną formą nauki.

\section{LITERATURA}

I Bączkowska A., 2010, Constructivism and constructionism in language and cognition, New Pathways in Linguistics, red. Stanisław Puppel, Marta Bogusławska-Tafelska, Olsztyn, s. 9-20.

I Bączkowska A., Krizis, kak prostranstwo issledowanij. Nowyje issledowatielskije naprawlenija $i$ woprosy [Кризис, как пространство исследований. Новые исследовательские направления и вопросы]. Wykład plenarny na konferencji: Mieżdunarodnaja naucznoprakticzeskaja on-lajn konfieriencyja „Krizisnyj mieniedżmient w obrazowanii. Nowyj opyt i praktika” [Международная научно практическая он-лайн конференция „Кризисный менеджмент в образовании. Новый опыт и практика"], 26.08.2020, Kazachstan: Uralsk-Nur-Sultan-Almaty. 
I Filipiak E., 2011, Z Wygotskim i Brunerem w tle: słownik pojęć kluczowych, Bydgoszcz.

I Fosnot C. T., 2005, Constructivism: Theory, Perspectives, and Practice, Nowy Jork.

I Piaget J. - Inhelder B., 1967 [1948], The Child's Concept of Space, New York.

I Root T., 2009, Opthobook, Scotts Valley, Kalifornia.

I Root T., 2016, Opthobook Questions. Volume One, Scotts Valley, Kalifornia. 